MICHAŁ PIECHOWICZ

Instytut Politologii UMK

\title{
Agregacyjna i integracyjna wizja wspólnoty politycznej według Jamesa Marcha i Johana Olsena a współczesne podziały w polskiej polityce
}

T

eorie, o których będzie mowa w niniejszym artykule, dotyczą kwestii projektu instytucjonalnego. Wśród instrumentów demokracji wyróżnia się między innymi instytucje polityczne. Jednak chcąc dowiedzieć się o nich więcej, należy zbadać obszar i sposoby pojmowania oraz myślenia na ich temat. Ten właśnie dylemat, który uważam za wyjątkowo interesujący, jest jednym z wielu, jakie poruszają w swojej książce zatytułowanej Instytucje, organizacyjne podstawy polityki James March i Johan Olsen.

Na wstępie należy przypomnieć, że zasadnicza idea teorii suwerenności ludu polega na tym, że wola ludu powinna ostatecznie przeważyć. Poddając tę myśl analizie od razu narzucają się konkretne pytania - kto należy do „ludu”, w jaki sposób rozpoznaje się jego wolę, jak długi okres kryje się pod stwierdzeniem „ostatecznie” oraz co dokładnie oznacza słowo „przeważyć”. Teorie różnią się w tej kwestii, stąd nie ma na nie jednoznacznej odpowiedzi. Jednak różnice te są bardzo istotne, ponieważ ich interpretacja przekłada się na rozróżnienie dwóch, całkowicie odmiennych procesów politycznych, nazwanych przez autorów agregacyjnymi oraz integracyjnymi ${ }^{1}$. Ponadto rozróżnienie to powiązane jest z kontrastem między kontraktowym a wspól-

\footnotetext{
${ }^{1}$ J. March, J. Olsen, Instytucje, organizacyjne podstawy polityki, Warszawa 2005, s. 147-148.
} 
notowym poglądem na organizację społeczną wyrosłym na rozróżnieniu społeczeństw na kolektywistyczne i indywidualistyczne.

\section{Proces agregacyjny}

Czym zatem wg teorii Marcha i Olsena jest agregacja, w jaki sposób interpretuje ona instytucjonalną polityczną rzeczywistość? Punktem wyjściowym jest suweren, czyli „lud” jako zbiór osób, które aktualnie mają prawo być traktowane jako obywatele. Jego wolę rozpoznaje się za pośrednictwem kampanii politycznych i przetargów między racjonalnymi z założenia obywatelami, z których każdy dąży do osiągnięcia własnej korzyści w ramach zbioru reguł rządów większościowych. Stąd teorie agregacyjne najczęściej zakładają porządek oparty na racjonalności i wymianie. Przywództwo $\mathrm{w}$ procesach agregacyjnych wiąże się z pośrednictwem koalicji między interesami. Bardzo istotny jest fakt, że teorie te kładą nacisk na natychmiastową reakcję na bieżące interesy ludu w oparciu i pełnym zaufaniu dla rządów większości. Zatem głównym wynikiem procesu politycznego jest polityka publiczna i odpowiednia alokacja zasobów ${ }^{2}$.

W większości współczesnych teorii suwerenności ludu panuje przekonanie, że systemy polityczne agregują różnorodne interesy indywidualne i grupowe w formie wyboru zbiorowego. Przyjmują one, że „lud”, który ma być reprezentowany, składa się z jednostek, jednostki te mają interesy (preferencje, potrzeby, pragnienia) oraz że te wspólne interesy są niespójne. Wynika z tego, że jednocześnie nie można w pełni zaspokoić potrzeb wszystkich osób. Problem polityczny polega zatem na ustaleniu procedury, na podstawie której alokacja rzadkich zasobów dokonywana jest w sposób zadowalający przy zachowaniu pluralizmu interesów i wartości. Pod tym względem March i Olsen, przyrównują systemy polityczne do systemów ekonomicznych, które opierają się na konkurencyjnych rynkach i cenach. Można zatem w skrócie podsumować, iż polityczne procesy agregacji są w zasadzie procesami interesów, władzy i wymiany. Pierwsze omówienia agregacji politycznej kładły nacisk na rolę kampanii wyborczych i głosowania jako sposobu rejestrowania indywidualnych preferencji. $W$ bardziej współczesnych ujęciach prawo wyborcze przedstawia się jako jeden $\mathrm{z}$ wielu zasobów wykorzystywanych w tworzeniu koalicji politycznych. Przyjmuje się, że uczestnicy polityczni przystępują do procesu z pewnymi zasobami (np. władzą) oraz interesami. Zatem kandydaci na urząd dążą do uzyskania poparcia osób, których połączona władza jest wystarczająca, aby zwyciężyć $\mathrm{w}$ wyborach, a następnie zaimplementować forsowane przez siebie pomysły.

\footnotetext{
${ }^{2}$ Patrz więcej w: tamże, s. 148-149.
} 
Idąc dalej, March i Olsen uważają, że politykę można postrzegać jako system agregowania indywidualnych preferencji przez dobrowolną wymianę. Z tego punktu widzenia wyniki polityki stanowią najczęściej rezultat jednoczesnej dbałości o indywidualne interesy przez jednostki, które posiadają egzogennie określone pozycje i zasoby, oraz które w ramach konstytucyjnej struktury dokonują wymiany, grożą, składają obietnice, tworzą koalicje i zawierają porozumienia, dopóki nie zostanie przyjęta dana polityka ${ }^{3}$.

\section{Proces integracyjny}

Jako przeciwieństwo agregacji autorzy usytuowali procesy integracyjne określające „lud” jako grupę, która istniała w historycznej przeszłości i będzie istniała oczywiście również w przyszłości. Wola „ludu” jest tu rozpoznawana przez obradowanie rozsądnych obywateli i władców, dążących do osiągnięcia powszechnego dobrobytu w kontekście wspólnych wartości społecznych. Teorie integracyjne najczęściej zakładają porządek oparty na historii, obowiązku oraz rozsądku. Bardzo istotnym elementem w pojmowaniu przywództwa jest przywiązanie do wypełnienia idei, „misji” np. edukacyjnej, oraz reprezentowania tradycji społecznych i przyszłych potrzeb. Integracja zakłada ewolucyjną adaptację systemu oraz ochronę przed chwilowymi porywami i racjonalnością. Zasada rządów większości włączona została w strukturę praw i norm instytucjonalnych. Wszystko to ma się kumulować w końcowym rezultacie, za jaki procesy integracyjne przyjmuja rozwój systemu politycznego opartego na wspólnym celu i zaufaniu ${ }^{4}$.

\section{Główne rozważania i problemy wynikające z podejścia integracyjno-agregacyjnego}

Autorzy zauważają, że we wszystkich współczesnych społeczeństwach demokratycznych dostrzega się ograniczenia polityki agregacyjnej. Jednym z powodów jest fakt, że wiele sfer społecznego wyboru jest wyłączonych z agregacyjnego procesu politycznego. Transakcje, koalicje i zakulisowe układy określa się jako niesprzyjające zdrowemu rozsądkowi, sprawiedliwości, efektywności i stosownej polityce. Przeważnie twierdzi się, że profesjonalne oceny prawników, lekarzy, naukowców, teologów powinny być chronione przed pochopnymi osądami i krótkookresowymi względami politycznymi. Politykę agregacji uważa się za istotną część każdego demokratycznego procesu politycznego, jednak teorie prawoznawstwa i administracji na ogół przyjmują, że instytucje społeczne nie tylko agregują indywidualne

\footnotetext{
Tamże, s. 150-154.

4 Tamże, s. 148-149.
} 
interesy, lecz także je kształtują i umożliwiają ich rozwój. Stąd zainteresowanie kwestiami związanymi $\mathrm{z}$ kształtowaniem znaczenia oraz tworzeniem preferencji stało się ważną częścią teorii organizacyjnego podejmowania decyzji, a także współczesnych instytucjonalnych poglądów na organizację społeczną. Integracyjne procesy polityczne $\mathrm{w}$ imię suwerenności ludu wyróżniają się dwiema głównymi cechami, które potencjalnie są zupełnie niezgodne z perspektywami agregacji przedstawionymi powyżej. Pierwszą stanowi koncepcja praw. Drugą jest idea racjonalnych rozważań w poszukiwaniu wspólnego dobra 5 .

March i Olsen argumentują, iż skoro koncepcja praw człowieka podporządkowuje zasady wymiany zasadom ludzkiej godności i uczciwości, stanowiła ona stały problem dla agregacyjnych teorii suwerenności ludu. Najczęstszym sposobem racjonalizacji praw człowieka w utylitarnych teoriach suwerenności ludu jest uznanie, że pewne prawa umożliwiają funkcjonowanie systemu demokratycznego. Na przykład prawa do wolności słowa i wolności prasy można postrzegać, zgodnie z taką interpretacją, jako instrumenty przyczyniające się do efektywnego odkrywania i realizowania wymiany politycznej. To instrumentalne uzasadnienie praw człowieka wpisuje je w koncepcję agregacyjnej suwerenności ludu, ale kosztem utraty sedna ich tradycyjnego znaczenia. W takim stopniu, w jakim prawo uzasadnia się z punktu widzenia jego roli w procesie politycznym, nie jest ono prawem, lecz narzędziem. Podobnie jak moralność i miłość, traci swój zasadniczy charakter jako uprawnienie, kiedy uzasadnia się je w kategoriach wpływu na urzeczywistnianie innych wartości. Dlatego rozgraniczenie praw politycznych jako instrumentów, których uzasadnienie stanowi ich rola w efektywnej agregacji indywidualnych preferencji, i praw człowieka jako nienaruszalnych i niezbywalnych symboli integracji kultury politycznej, jak również tożsamości i obowiązków obywateli, jest wyraźnie obecne w rozróżnieniach współczesnych wersji instytucji agregacyjnych oraz integracyjnych. $\mathrm{W}$ procesie agregacyjnym prawa są albo regułami ustanowionymi w celu poprawienia niedoskonałości systemu wymiany, albo zasobami podzielonymi jako początkowe wyposażenie i dostępnymi do bezpośredniej wymiany. $\mathrm{W}$ procesie integracyjnym natomiast prawa stanowią wyraz kluczowych aspektów struktury przekonań społecznych. Są metaforami ludzkiej jedności, symbolizującymi wspólny los i człowieczeństwo osób, które je podzielają. Bez wątpienia jeden z podstawowych celów integracyjnego procesu politycznego stanowi odkrycie i uszczegółowienie znaczenia tych fundamentalnych wartości. Druga podstawowa różnica między trady-

\footnotetext{
${ }^{5}$ Tamże, s. 155-156.
} 
cjami integracyjnymi a agregacyjnymi polega na roli racjonalnych rozważań w poszukiwaniu wspólnego dobra, którym powinien kierować się system. Procesy integracyjne traktują konflikt interesów jako podstawę rozważań i obowiązujących decyzji, a nie przetargu. Kieruje nimi logika jedności, nie zaś logika wymiany. Ich istotą jest proces, w którym rozwija się wzajemne zrozumienie, wolę zbiorowości, zaufanie i solidarność. Mają one na celu syntezę i konwersję, a nie antytezę i ustępstwa. Kluczowe integracyjne procesy polityki służą tworzeniu identyfikacji i realizacji wspólnych preferencji. Wymagają one klasycznych działań politycznych - namysłu, dyskusji, debaty, edukacji, przymusu i wykorzystania zgromadzonego społecznego doświadczenia zapisanego w specjalistycznej wiedzy i powszechnie przestrzeganych regułach. Koncepcja instytucji jako ucieleśnienia oraz instrumentu wspólnoty, lub porządku demokratycznego jako systemu konstytucyjnego, stanowi istotny aspekt myśli instytucjonalnej. Znajduje ona odzwierciedlenie zarówno w dawnych, jak i we współczesnych omówieniach wspólnych kultur, zbiorowej tożsamości, poczucia przynależności, więzi, wzajemnego przywiązania, wspólnych wizji, symboli, historii, wzajemnego zaufania i solidarności ${ }^{6}$.

Najbardziej zauważalne praktyczne problemy współczesnych instytucji agregacyjnych związane są z ich niezdolnością do rozwiązywania problemów preferencji i wyposażenia. Przy założeniu, że w świetle koncepcji efektywnej wymiany aktorzy mają spójne, stabilne i egzogenne preferencje, należy zauważyć, że często w praktyce okazuje się, iż subiektywnie odbierane interesy polityczne przeważnie są niespójne, niestabilne i endogenne. Taka niejednoznaczność rodzi stosunkowo poważne problemy dla systemów suwerenności ludów. Wywołała ona nieustanną dyskusję, czy słuszny jest pogląd, że informacje pochodzące ze środków przekazu lub od przywódców politycznych modyfikują oczekiwania wyborców czy też ich interesy? A jeśli mamy do czynienia z drugim przypadkiem, to czym charakteryzuje się stosowne modyfikowanie preferencji? Niejasność doprowadziła także do wysuwania twierdzeń o rozbieżnościach między subiektywnymi interesami obywateli, a ich „prawdziwymi” interesami oraz obiektywną rzeczywistością ich stanu. Dlatego instytucje agregacyjne mają trudności z właściwym interpretowaniem i udoskonalaniem sposobów reagowania przez demokratyczne instytucje na niejednoznaczne, zmienne interesy obywateli. Ze względu na wspomniane trudności często apelowano o ingerencję władz państwowych $\mathrm{w}$ agregacyjny system służący interesom aktualnych wyborców. Takie apele oznaczają uznanie, że państwo jest powiernikiem ważnych

\footnotetext{
${ }^{6}$ Patrz więcej w: tamże, s. 156-161.
} 
segmentów wspólnoty, które słabo są reprezentowane w polityce lub nie mają do niej dostępu. Wymownym przykładem będą tu grupy społeczne, do których można zaliczyć ubogich czy nienarodzonych. Twierdzi się, że mają oni prawo do reprezentacji, że każdy agregacyjny system polityczny pozbawia ich tego prawa, a zatem jedynie wskutek interwencji ich powierników, czyli instytucji państwowych, mogą być odpowiednio chronieni. Powyższa argumentacja staje się bardziej przekonująca, gdy inne instytucje (np. rodzina) stają się mniej wiarygodnymi powiernikami. Twierdzenie można uogólnić, identyfikując państwo jako nośnik kultury lub cywilizacji oraz uznając potrzebę ochrony tej tradycji przed chwilowymi porywami współczesnych większości lub wpływowych mniejszości. Z kolei najbardziej zauważalne praktyczne problemy współczesnych instytucji integracyjnych związane są z ich niezdolnością do zagwarantowania uczciwości, kompetencji i racjonalnej debaty w życiu politycznym. Integracja wymaga poczucia sensu i otwartości w dążeniu do wspólnego dobra. Wymaga dobrej wiary i próby rozpatrywania polityki publicznej jako instrumentu wspólnoty, podporządkowania własnych potrzeb i indywidualnych pragnień poczuciu interesu publicznego określonego przez wspólnotę, a także niewzruszonego przekonania, że podobnego zaangażowania i podporządkowania można oczekiwać od innych. Reasumując, wymaga obywatelskiego ducha w społeczeństwie?.

\section{Podsumowanie teorii agregacji i integracji}

Próbując podsumować założenia teoretyczne, trzeba zauważyć, że sposób połączenia procesów agregacyjnych oraz integracyjnych w instytucjach zmienia się z upływem czasu, oscylując między instytucjonalnymi strukturami i teoriami suwerenności ludu, które koncentrują się na funkcjach agregacyjnych, a strukturami i teoriami, które kładą nacisk na funkcje integracyjne. Wyrazem wspomnianych przeobrażeń w połączeniu może być homogeniczny zwrot we wszystkich instytucjach lub zmiana liczby stosunkowo czystych instytucji agregacyjnych w porównaniu do stosunkowo czystych instytucji integracyjnych. Inną istotną kwestią jest fakt, że w ciągu ostatnich kilkudziesięciu lat cykl rozwojowy tych procesów znajdował się $\mathrm{w}$ fazie agregacji. Demokracje zachodnie wykazywały tendencję do nadawania instytucjom bardziej agregacyjnego charakteru oraz do zmniejszania różnic między nimi. Teorie ewaluacji instytucjonalnej również przyjęły bardzo agregacyjną postać, kładąc nacisk na kwestie efektywności alokacyjnej i przykładając mniejszą wagę do spraw preferencji, wyposażenia, kompeten-

\footnotetext{
7 Patrz więcej w: tamże, s. 164-167.
} 
cji, uczciwości i skuteczności. March i Olsen zauważają, że od lat siedemdziesiątych dwudziestego wieku założenia liberalnego indywidualizmu przeniknęły całe życie społeczne, a równocześnie następowała erozja takich sił jak miłość, przyjaźń, solidarność, rodzina, altruizm, a także pozostałości religii i innych ugruntowanych światopoglądów, które tradycyjnie ograniczały zachowanie całkowicie ukierunkowane na korzyść własną. Wprawdzie obecnie agregacyjne instytucje i teorie polityczne odgrywają przeważającą rolę, jednak wydaje się prawdopodobne, że w ciągu najbliższych lat naturalne procesy cyklicznych zmian osłabią ich dominację. Formy agregacyjne są szczególnie charakterystyczne dla „dobrych czasów”. Nadmiar zasobów w stosunku do bieżących potrzeb stanowi bufor między sprzecznymi siłami w społeczeństwie oraz ułatwia dobrowolną wymianę, która ma fundamentalne znaczenie dla procesów agregacji. Z kolei, w przypadku ograniczania dostępnych zasobów, zwiastować można rozwój struktur integracyjnych ${ }^{8}$.

\section{Teorie kolektywizmu i indywidualizmu w organizacji kultur i społeczeństw}

Myliłby się ten, kto mimo świeżości osądów i interesujących teorii Marcha i Olsena, uznałby je za wyjątkowo przełomowe. Zapewne teoria agregacji i integracji na stałe już zapisała się $\mathrm{w}$ zagadnienia teorii polityki. Należy jednak zauważyć, że typowo politologiczne agregacyjno-integracyjne spojrzenie na zagadnienia projektu instytucjonalnego wyrasta na o wiele szerszym dyskursie dotyczącym kolektywnej (wspólnotowej) organizacji kultur i społeczeństw, a przeciwstawnej jej indywidualistycznej. Rozprawa na ten temat może być oparta o antropologię kulturową, badania z dziedziny socjologii, psychologii, ekonomii czy w końcu politologii. Ponieważ podział na świat myśli kolektywnej i indywidualistycznej dotyczy każdej dziedziny życia, natomiast myśli Marcha i Olsena są teoriami typowo politologicznymi, godne uwagi jest znalezienie podobieństw i dogmatycznych podstaw teorii agregacyjno-integracyjnych i kolektywno-indywidualistycznych, ponieważ często zrozumienie idei agregacji/integracji wynika z kulturowego zaprogramowania społeczeństw i ich wyjątkowego spojrzenia na otaczającą rzeczywistość, a w związku z tym także odrębnych oczekiwań wobec państwa.

\footnotetext{
${ }^{8}$ Tamże, s. $168-170$.
} 


\section{Kolektywizm i indywidualizm jako rozróżnienie społeczno-kulturowe}

Omawiając wspomniane zagadnienia, należy wyjść od tezy stanowiącej, że ludzie, społeczeństwa i kultury różnią się ze względu na to, czy widzą człowieka jako odrębną, autonomiczną jednostkę, która ma prawo dawać pierwszeństwo swoim osobistym dążeniom i pragnieniom, a nie kierować się dobrem grupy albo większej całości, której jest członkiem, czy ujmują jednostkę jako integralną część większej całości ${ }^{9}$, w której jest „bytem wtórnym", podporządkowanym celom i interesom owej całości. Pojęcia „indywidualizm” i „kolektywizm” wyraźnie nawiązują do dwóch podstawowych form organizacji życia społecznego, które zaproponował Ferdynand Tönnies w 1887 roku, czyli do „wspólnoty” ${ }^{10}$, będącej idealnym typem struktury kolektywistycznej, i „stowarzyszenia”"11, będącego idealnym typem struktury indywidualistycznej. Pierwotnie badacze używali tych pojęć w celu opisu historycznego przejścia od wspólnot agrarnych do nowoczesnej ekonomii i państw narodowych. Współcześnie rozróżnienie to sprowadza się do stwierdzenia, iż wspólnotę charakteryzuje to, że jej członkowie „wzajemnie do siebie należą", posiadają i użytkują wspólne dobra, odczuwają te same przyjemności i przykrości, mają wspólnych przyjaciół i wrogów. Z kolei w stowarzyszeniu ludzie żyją obok siebie, ale nie są ze sobą silnie związani ${ }^{12}$. Ujęcie indywidualistyczne zakłada, że świat społeczny jest zbiorem odrębnych jednostek, które samodzielnie starają się określić i realizować optymalne sposoby życia. Człowiek definiuje siebie samego, określa swoją tożsamość poprzez odróżnienie „ja” - „inni”, a nie poprzez przynależność do większej całości ${ }^{13}$. Podobnie twierdzi Hofstede ${ }^{14}$ głosząc, że indywidualizm oznacza taki sposób funkcjonowania społecznego, w którym związki między ludźmi są luźne, doraźnie tworzone przy realizacji rozmaitych zadań, gdzie oczekuje się, że każdy będzie się troszczył o siebie i swoją rodzinę. W społe-

\footnotetext{
${ }^{9}$ Tą większą całością może być zarówno grupa rodzinna, przedsiębiorstwo, organizacja polityczna lub społeczna, czy w końcu państwo i naród.

${ }^{10} \mathrm{Niem}$. Gemeinschaft, ang. community.

${ }^{11}$ Niem. Gesellschaft, ang. association.

${ }^{12}$ K. Skarżyńska, Człowiek a polityka, Warszawa 2005, s. 26.

${ }^{13}$ Tamże, s.29.

${ }^{14}$ Geert Hofstede na podstawie badań około 110 tysięcy osób zatrudnionych w firmach związanych z IBM na całym świecie, stwierdził, że wymiar indywidualizm-kolektywizm wyjaśnia najlepiej międzynarodowe różnice w postawach ludzi. Czynnik indywidualizmkolektywizm podzielił stworzoną przez niego psychogeograficzną mapą świata na dwie części: indywidualistyczną Europę Zachodnią i USA oraz kolektywistyczną „resztę”, w których prym wiodą najbardziej skolektywizowane społeczeństwa Azji.
} 
czeństwach indywidualistycznych normą jest uniwersalizm, czyli jednakowe traktowanie wszystkich ludzi, bez względu na to, czy należą do grupy określanej jako „my” czy do jakiejkolwiek grupy zewnętrznej - „oni”. Z kolei charakteryzując społeczeństwa kolektywne Hofstede zauważa, że w nich ludzie od urodzenia do śmierci przynależą do takich samych silnie zintegrowanych grup, które w zamian za lojalność, roztaczają nad nimi swoją opiekę. Ludzi traktuje się partykularnie, tzn. inaczej tych, którzy są przyjaciółmi, a inaczej osoby spoza własnej grupy ${ }^{15}$. Ciekawe spostrzeżenia przedstawił także Edward T. Hall, który zauważył, że społeczeństwa indywidualistyczne wysoko cenią autonomię jednostki i dbałość o własny interes. Decyzje są podejmowane szybko, ponieważ niewiele osób w tym wypadku jest włączonych $\mathrm{w}$ ten proces. Życie codzienne wymaga wysokich umiejętności i kwalifikacji, aby sprostać wymogom współzawodnictwa. Społeczeństwa te są przyszłościowo zorientowane, stąd szybkie tempo życia jest naturalnym stanem. Tymczasem ludzie zintegrowani w społeczności kolektywnej myślą terminem „my”, a w mowie i piśmie często porzuca się słowo „ja”. Rodzina, przodkowie, dziedzictwo oraz patriotyzm są bardzo ważną częścią egzystencji. Introwertyzm członków społeczności współgra z faktem, że opinie i stanowiska są artykułowane przez grupę bądź lidera grupy. Podejmowanie decyzji zabiera więcej czasu w porównaniu do świata indywidualistycznego. W relacjach międzyludzkich preferuje się jednolitość i równość nad wolność osobistą. Społeczeństwa kolektywne są zorientowane na przeszłość, stąd troska o tradycję i rytuały ${ }^{16}$.

\section{Kolektywizm i indywidualizm jako rozróżnienie polityczne}

Po krótkiej charakterystyce i ogólnym wprowadzeniu w zagadnienia indywidualizm - kolektywizm, czas zająć się przełożeniem tych teorii na świat polityki oraz uchwycić różne spojrzenia na życie społeczne i instytucjonalne obu nurtów. Rozróżnienie to, podobnie jak w dyskursie agregacyjno-integracyjnym, przekłada się na odmienne pojmowanie prawomocności władzy, rozumienie praw człowieka oraz akceptowanie reguł podziału dóbr i przypisywania odpowiedzialności. Zgodnie z założeniami kolektywistycznymi władza jest atrybutem grupy, wyrazem woli, którą rozpoznaje się w większościowym głosowaniu, poprzez konsensus $\mathrm{w}$ debacie czy decyzję grupowej elity lub konkretnego przywódcy. Władza prawomocna jest więc rozumiana jako sprawowana dla dobra grupy. Procedura jej wyboru

${ }^{15}$ G. Hofstede, G. J. Hofstede, Cultures and Organizations. Software of the Mind, New York 2005, s. 74-78. [Polskie wydanie: Ciż, Kultury i organizacje: zaprogramowanie umysłu, Warszawa 2000 lub 2007]

${ }^{16}$ E. T. Hall, Understanding Cultural Differences, Yarmouth, 1990. 
jest mniej ważna niż przekonanie, że dobrze służy interesom całości. Z kolei zgodnie z założeniami indywidualistycznymi podstawowym kryterium legalności czy prawomocności władzy jest spełnienie kryteriów proceduralnych dotyczących dochodzenia do władzy oraz reguł jej sprawowania. Omówione rozróżnienie pozwala lepiej zrozumieć, dlaczego niektórzy obywatele są w stanie akceptować naruszanie procedur demokratycznych państwa dla „narodowego dobra”, a inni oburzają się, gdy ktoś, nawet w słusznej sprawie, łamie procedury i sięga po uprawnienia, których prawo nie daje. Podobnie, jeśli weźmiemy pod uwagę kwestię praw człowieka, indywidualizm i kolektywizm nie znajdą wspólnej płaszczyzny. Otóż w ujęciu wspólnotowym prawa człowieka są wtórne wobec praw i interesów grupy, ponieważ to ona jest ich źródłem. Natomiast założenia indywidualistyczne przyjmują istnienie praw, które przysługują każdej jednostce (na przykład prawo do autonomii i wolności). Ograniczenie ich może nastąpić tylko na drodze umowy między zainteresowanymi jednostkami, które widzą korzyści płynące z rezygnacji (najczęściej czasowej lub częściowej) z niektórych praw w celu ochrony swoich podstawowych interesów ${ }^{17}$. Jak zostało wspomniane $\mathrm{w}$ części pracy poświęconej teoriom Marcha i Olsena, to instytucje społeczne oraz polityczne należą do podstawowych instrumentów demokracji. Jednak również ich pojmowanie na płaszczyźnie indywidualistycznej i kolektywnej różni się. We wspólnocie za podstawę uznaję się instytucję obyczaju opartą o przyzwyczajenie i nawyki. $\mathrm{Z}$ kolei $\mathrm{w}$ stowarzyszeniu podstawą jest instytucja konwencji opartej na postanowieniu i zatwierdzeniu, gdzie społeczeństwo jest zbudowane na zasadzie kontraktu ${ }^{18}$. W wymiarze politologicznym idealną instytucją dla indywidualisty jest demokratyczny legalizm, czyli rządy prawa, gdzie istotą jest ograniczenie społecznej i ekonomicznej roli państwa, przy zachowaniu jego skuteczności oraz zabezpieczenia obywatela przed ingerencją władzy. Z kolei dla kolektywisty najwłaściwszą instytucją jest demokratyczne uczestnictwo, gdzie istotą jest poczucie skuteczności politycznej, powszechne zainteresowanie problemami społecznymi, redystrybucja środków materialnych oraz wyrażanie i egzekwowanie decyzji zbiorowych. Należy zauważyć, że indywidualista podkreśla polityczny aspekt władzy, której prerogatywy powinny być skromne, a odpowiedzialność ograniczona. System hierarchizacji przywództwa $\mathrm{w}$ indywidualizmie to biurokracja, a więc zgodne $\mathrm{z}$ jasno określonym prawem delegowanie zwierzchnictwa ludziom kompetentnym. Przymus użyty przez władzę jest dla indywidualisty

\footnotetext{
${ }^{17}$ K. Skarżyńska, dz.cyt., s. 30.

${ }^{18} \mathrm{Z}$ powyższym wiąże się inne interpretowanie pojęć ze sfery aksjologicznej. Dla indywidualisty wolność to prawo do nierówności, równość zaś może być zamachem na wolność. W postrzeganiu kolektywistycznym wolność osiąga się przez zrównanie.
} 
łatwiejszy do zaakceptowania, ponieważ jest on oparty na przepisach prawa. Ciekawym jest, że władza w rozumieniu indywidualisty ma za zadanie przede wszystkim stworzyć warunki uczciwego współzawodnictwa o dobra prywatne, a sprawiedliwość indywidualistyczna to sprawiedliwość proceduralna. Z kolei kolektywista akcentuje obywatelski aspekt władzy. Przywództwo jest tu obowiązkiem i uprawnieniem każdego obywatela. Obywatele zaś przekazują swoje uprawnienia na polityków, którzy są całkowicie przed nimi odpowiedzialni. System hierarchizacji przywództwa w kolektywizmie to nomenklatura - władza dla swoich. Kolektywista rozpatruje przymus jako użyty przeciw legalnemu podmiotowi władzy, a więc obywatelom, stąd jego akceptacja jest trudniejsza. W strukturach kolektywistycznych kryzys panowania przejawia się alienacją, czyli poczuciem bezsilności obywatela wobec organów państwowych. W jego mniemaniu głównym zadaniem władzy jest stworzenie warunków sprawiedliwego dostępu do dóbr publicznych, stąd sprawiedliwość kolektywistyczna to sprawiedliwość dystrybutywna ${ }^{19}$.

\section{Podobieństwa i ideologiczne podstawy omówionych teorii}

Każdy, kto uważnie prześledził najistotniejsze cechy odróżniające podejście agregacyjne od integracyjnego oraz zróżnicowanie indywidualistyczno-kolektywistyczne, musiał zauważyć powtarzające się podobieństwo na linii agregacja-indywidualizm oraz integracja-kolektywizm. W pierwszej kolejności zastanówmy się nad najistotniejszymi podobieństwami łączącymi teorie integracyjne z kolektywizmem. Oba nurty otaczają dużym zainteresowaniem historię, oraz kultywują stworzony przez nią porządek. Ponadto rozwój systemu politycznego opiera się na wspólnym celu i zaufaniu, procesami decyzyjnymi kieruje logika jedności, a wszystko to w ramach prawomocnej władzy, która jest wyrazem woli grupy i na zasadzie rządów większości jest sprawowana dla wspólnego dobra całej wspólnoty. Inną płaszczyznę ideową można odnaleźć, porównując teorie agregacji z indywidualizmem. Podstawą w tym przypadku jest teza głosząca, że każdy człowiek jest z założenia rozsądnym obywatelem i w swoim działaniu dąży do realizacji własnych zamierzeń w ramach zbioru przyjętych reguł. Każdy człowiek posiada także katalog praw, z których $\mathrm{w}$ określonych wypadkach jest w stanie zrezygnować na rzecz państwa, jeśli widzi w tym własny interes. Stąd oczekiwania wobec rządów państw w rozumieniu stowarzyszenia, w porównaniu do poprzedniej wspólnoty ideowej, są minimalne, a zbudowany na zasadzie kontraktu idealny demokratyczny legalizm ma $\mathrm{m}$. in. na celu ograniczenie spo-

\footnotetext{
${ }^{19}$ Podstawy nauk politycznych, K. A. Wojtaszczyk, W. Jakubowski (red.) , Warszawa 2003, s. 145.
} 
łecznej i ekonomicznej roli państwa przy zachowaniu jego skuteczności oraz należytego zabezpieczenia obywatela przed ingerencją władzy.

\section{Subsumcja teorii Marcha i Olsena w realia współczesnej sceny politycznej w Polsce}

To, o czym była do tej pory mowa, jest niezwykle ciekawą analizą teoretyczną, pozwalającą zrozumieć istotę opisanych procesów, rządzące nimi procedury oraz ich cykliczność. Ciekawą kwestią, której proponuję teraz się przyjrzeć, jest próba analizy współczesnej polityki w naszym kraju, biorąc za punkt odniesienia i podstawę rozważań teorie, o których jest mowa w książce Jamesa Marcha i Johana Olsena Instytucje, organizacyjne podstawy polityki.

Z pewnością niezaprzeczalnym faktem jest, że w Polsce od wyborów z września 2005 roku następują przemiany, których tempo i zasięg można porównać, na tle historii III Rzeczpospolitej, jedynie do zmian z przełomu lat 1989/90. Przyszłość pokaże, czy ten moment zmian na scenie politycznej okaże się dziejowo przełomowym. Można natomiast zaryzykować stwierdzenie, iż obecnie zmieniają się same podstawy polskiej polityki. Po półtorarocznych obserwacjach, komentując bieżące wydarzenia nie można już mówić tylko o pęknięciach, swojego rodzaju grze czy doraźnej koalicji. Rządząca koalicja bowiem szukając nowych haseł, być może celowo, a możliwe, że zupełnie przypadkowo, odwołała się w swojej ideologicznej tożsamości do ideowej płaszczyzny, która jest głębsza niż obowiązujący przez ostatnie 15 lat podział na „postkomunę” i „postsolidarność”. W 2005 roku zachowania wyborcze Polaków po raz pierwszy obracały się wokół nowych haseł solidaryzmu i liberalizmu. Nowa płaszczyzna podziału, a zarazem wyboru obywateli, skupiła się na dwóch odmiennych wizjach wspólnoty politycznej (państwa). Część wyborców opowiedziała się za integracyjną wizją, drudzy za agregacyjną. W polskiej grze politycznej agregacyjne podejście do instytucji politycznej można zinterpretować w następujący sposób. Wola „ludu” jest odczytywana poprzez kumulację istniejących i doraźnych preferencji obywateli. Istotny jest też wyraźny mechanizm rozstrzygania, ponieważ zawsze realizowana jest wola większości. Jeśli w danym okresie gospodarka, przedsiębiorcy oraz reprezentowane przez agregacyjne podejście zintegrowane grupy uważają, że podatek liniowy jest najbardziej korzystnym rozwiązaniem, w związku z tym podatek ten należy wprowadzić. W sytuacji, w której największym problemem finansów publicznych jest powiększająca się „dziura budżetowa”, najistotniejszym celem rządu jest przeprowadzenie reformy finansów publicznych. Jeżeli środowiska biznesowe otwarcie mówią, 
że największym problemem w prowadzeniu działalności, zwłaszcza drobnej przedsiębiorczości, są wysokie koszta pracy, w związku z tym ich obniżenie będzie głównym czynnikiem jaki ma służyć spadkowi bezrobocia ${ }^{20}$. Chcę zauważyć, że w każdym z tych przypadków widoczna jest wiara, jaką pokłada w społeczeństwie polityka agregacyjna. Państwo jest w tym przypadku stowarzyszeniem obywateli, służebnym wobec ich artykułowanych potrzeb. $\mathrm{Z}$ kolei w polskim modelu integracyjnym państwo jest czymś daleko większym. Postrzega się je i interpretuje jako wspólnotę zarówno pokoleń przeszłych, jak i przyszłych. Doraźna wola wyborców, nawet jeśli jest to wola większości, nie zawsze rozstrzyga, jaki program ma być realizowany, ponieważ ktoś musi myśleć o interesach tych, którzy w tym momencie są poza "ludem”, np. nienarodzonych. Najlepszym tego przykładem jest zaistniały w kwietniu 2007 roku, najpoważniejszy jak dotąd, kryzys wewnętrzny w PiS. Marszałek Sejmu odszedł z partii rządzącej i powołał nowe chrześcijańskokonserwatywne ugrupowanie. Oczywistym jest, że kwestia aborcji i ochrony życia od zawsze budziła w społeczeństwie polskim wiele emocji i skrajnie różnych opinii. Nigdy jednak nie powodowała kryzysów rządowych. Na tle teorii integracji nie powinno to jednak dziwić, ponieważ w tym wypadku ta właśnie kwestia jest ideologicznie jedną z fundamentalnych. $\mathrm{W}$ podejściu tym pojawia się także idea misji, przekonanie, że obywatele mogą nie rozumieć tego, co jest interesem państwa, interesem przyszłości, że trzeba ich odpowiednio wychowywać, a państwo ma spełniać w tym przypadku rolę kurateli. Zatem gdy spojrzymy na PiS, LPR czy Samoobronę bez trudu można doszukać się w tym trio właśnie integracyjnej wizji państwa, którą na użytek wyborczy nazwano wizją solidarną. Samoobrona zawsze przecież taką wizję podzielała. W jej frazeologii eksponowano, że to „złe” państwo nie zajmuje się ludźmi i jest głównym odpowiedzialnym za ich wszystkie niepowodzenia. W tym populistycznym rozumieniu to właśnie państwo sprowadza do kraju zboże ze wschodu zamiast kupić je od miejscowych rolników. Problem $\mathrm{w}$ tym, że to uproszczone wnioskowanie nie współgra $\mathrm{z}$ sytuacją na międzynarodowym rynku zbóż. To jednak nie jest w tym momencie ważne. Zboże należy wysypać, aby pokazać „złemu” państwu, że rolnicy są niezadowoleni. Ten prosty schemat i nie do końca zgodne z prawdą rozumowanie można zastosować w wielu przypadkach, np. emerytów i kwestii podwyżek cen lub braku rewaloryzacji świadczeń emerytalnych czy w przypadku stoczniowców i braku chętnych na budowę statków w ich zakładzie pracy. Nie rozważając za każdym razem istoty problemu, złem obarcza się państwo, które nie pomaga obywatelom, stąd ktoś taki, jak Andrzej Lepper, musi się

\footnotetext{
${ }^{20}$ To podejście w teorii wykazuje wiele cech wspólnych z liberalizmem.
} 
o nich zatroszczyć. Podobnych schematów można doszukać się w działaniu i argumentowaniu Prawa i Sprawiedliwości, które od dwóch lat ukazuje nieustannie jak fatalnym pomysłem na Polskę było dotychczasowe 16 lat Trzeciej Rzeczpospolitej. Likwidując WSI chciano udowodnić jak bardzo niezdrowe było państwo polskie. W tym samym czasie przedstawia się zarazem lekarstwo na tę chorobę, jakim jest pomysł budowania nowej IV RP w oparciu o uczciwość i solidarny naród. W koalicyjne trio wchodzi także LPR, które najgłośniej argumentuje swoją troskę o przyszłe pokolenia, o polską tożsamość kulturową i narodową. Analizując działania Romana Giertycha jako Ministra Edukacji zauważamy książkowy model niektórych elementów integracyjnej polityki. Budowanie wspólnej tożsamości narodowej w oparciu o historię i religię, którą proponowano podnieść do rangi przedmiotu maturalnego, plany wprowadzenia nowego przedmiotu pod nazwą „wychowanie patriotyczne", które mogliby nauczać wojskowi, aby wprowadzić w szkołach należytą dyscyplinę czy choćby krążące po szkołach tzw. „trójki”, prowadzące inspekcje dotyczące zachowania uczniów i bezpieczeństwa na terenie szkół, to sztandarowe przykłady. Biorąc pod uwagę działania partii rządzących, oraz fakt, że każde z tych haseł jest fundamentem postrzegania wspólnoty politycznej w wizji integracyjnej, nie można bez głębszej analizy prymitywizować zaistniałego, nowego podziału w polskiej polityce. Analizując tą tezę dalej, trzeba zauważyć, że od 1989 roku do niedawna dominowały w Polsce procesy, które w większości wykazywały cechy agregacyjne. Stylem sprawowania władzy były zazwyczaj ciche transakcje, przetargi, zakulisowe układy, co jest sprzeczne i niedopuszczalne z punktu widzenia integracji, ponieważ jest niesprawiedliwe. Nie da się zaprzeczyć, że zawsze w przetargu agregacyjnym ktoś traci, aby zyskać mógł inny. Taka logika wymiany przeczy solidarności i jedności społeczeństwa. Dopiero po wyborach z 2005 roku, nowa koalicja reprezentuje nurt zupełnie odmienny od dotychczasowego stylu rządzenia Polską. Stąd nie można się dziwić całkowitej negacji przeszłości, ponieważ fundamenty tych wizji są tak różne. Dlatego jeżeli uwzględnimy, że Andrzej Lepper i bracia Kaczyńscy razem opowiadają się za integracyjnym modelem, dodamy do tego ich antyelityzm i całkowitą negację dokonań III RP, to może się okazać, że ich sojusz przetrwa o wiele dłużej niż jeszcze niedawno się spodziewano. W tym miejscu trzeba także zwrócić uwagę na wielką szansę przed jaką stoją dziś PiS - jako przedstawiciel integracyjnej koalicji oraz PO - jako naturalny przeciwstawny im orędownik agregacyjnej polityki. Myślę, że teoria agregacji może być dla Platformy Obywatelskiej dobrym usprawiedliwieniem wobec zarzutów o jej bierność i bycie mało efektywną opozycją. Analizując poczynania rządu w ciągu ostatnich miesięcy, gdzie dyskusje często toczyły się wokół 
wspomnianych kwestii planowania rodziny, pomysłów Ministra Edukacji czy wybraniu Matki Boskiej na Królową Polski, PO ideologicznie została wykluczona z tej debaty. W myśl „technicznego" i realistycznego podejścia do kwestii zarządzania państwem żadne $\mathrm{z}$ wymienionych dylematów rządowych nie było sferą zainteresowania polityki agregacyjnej. W tym wypadku aby zaistnieć w publicznej dyskusji, PO musiało odnaleźć się w sytuacjach, co do których w innych warunkach nie zabierałoby zdecydowanego, a może nawet żadnego stanowiska, ponieważ agregacja omawianą sferę ludzkiej działalności zostawia wolnej woli obywateli.

\section{Podsumowanie}

Widząc tak wyraźne różnice w sposobie myślenia i pojmowania wspólnoty politycznej, chcąc przewidzieć ewentualny rozwój zaistniałej sytuacji, myślę, że jeśli zarówno PiS oraz PO wykorzystają swoją szansę i nowy zaistniały podział socjopolityczny, jeśli staną się prawdziwymi wyrazicielami teoretycznych założeń, o których była mowa, to można spodziewać się określenia nowego, zasadniczego podziału i zajęcia przez nie dominujących miejsc na scenie politycznej w najbliższej przyszłości, a być może i na trwałe. Zawsze bowiem ktoś będzie musiał reprezentować konkretną wizję i ponieść hasło Polski solidarnej, socjalnej, troszczącej się o obywatela, oraz polski liberalnej, wierzącej w siłę i słuszność wyborów „ludu”, Polski będącej wyrazicielem aktualnych preferencji żyjących obywateli. Oczywiście realnie analizując polską scenę polityczną należy zauważyć, iż obecnie w polskim pluralizmie nie może być mowy o wyłącznie dwubiegunowym podziale, jednak utrzymanie dominacji tych dwóch sztandarowych reprezentantów teorii Marcha i Olsena jest bardzo realne. 


\section{J. March and J. Olsen's aggregated and integrated vision of political community according to recent partitions in Polish policy}

Theories being analysed in the article below concern an institutional project. Democratic instruments are based on, inter alia, political institutions. However, more precise analysis of mentioned aspects demand detailed examination of the field, methods of action and a paradigm of exploring the subject. This particular matter is one of the famous book's of James March and Johan Olsen "Rediscovering Iinstitutions. The Organizational Basis of Politics" fields of interest. The article based on the mentioned book refers to a proposition of a political process' division into aggregated and integrated forms.

As far as the first form is concerned, the analysis is based on the notion of the people, considered as an aggregation of individuals possessing the civic rights. Its will is expressed on the occasion of political campaigns, when the fight of each side for its own benefits is limited by the democratic rules. That is why the theories of aggregation usually take into consideration an order based on the rationality and exchange. What also needs to be stressed, is the fact that the conditions of an immediate reaction to the people's needs and a situation of total confidence are assumed. Therefore, the main result of the political process is a public policy and a proper allocation of resources.

As an opposition to the aggregation, the integrating processes are described as these considering the people as a group having existed since the historical past and supposed to exist also in the future. The people's need is communicated by the debates of the reasonable citizens and their governors whose aim is to achieve a common welfare and shared social values. A significant aspect of these theories is a historical order's importance, as well as the need of realising an idea, a mission and the traditions' representation. In such conditions, an adaptation of political is protected from irrationality. The processes' of integration aim is to develop a political system based on a common purpose and the confidence.

After a broad explanation of March and Olsen's theories they are implemented into recent conditions of Polish policy. 